2015 Global Fashion Management Conference at Florence Proceedings: 68 (June 2015) http://dx.doi.org/10.15444/GFMC2015.01.03.04

\title{
LUXURY BRANDS SOCIAL MEDIA MARKETING EFFORTS: INFLUENCE ON BRAND EQUITY AND CONSUMERS' BEHAVIOR
}

\author{
Bruno Godey, NEOMA Business School, France ${ }^{1)}$ \\ Aikaterini Manthiou, NEOMA Business School, France \\ Daniele Pederzoli, NEOMA Business School, France \\ Joonas Rokka, NEOMA Business School, France \\ Gaetano Aiello, University of Florence, Italy \\ Raffaele Donvito, University of Florence, Italy \\ Rahul Singh, Birla Institute of Management Technology, Greater Noida, India
}

\begin{abstract}
There is relatively little evidence on how social media marketing activities influence brand equity creation and consumers' behavior towards the brand. We explore these relationships by analyzing pioneering brands in the luxury sector (Burberry, Dior, Gucci, Hermès, and Louis Vuitton). Based on a survey of 845 luxury brand consumers (Chinese, French, Indian and Italian) who follow the five brands studied on social media, we developed a structural equation model that helps to address gaps in prior social media branding literature. Specifically, our study demonstrates the links between social media marketing efforts - measured as a holistic concept incorporating five aspects (entertainment, interaction, trendiness, customization and word of mouth) and their consequences (brand preference, price premium and loyalty).
\end{abstract}

Keywords: social media marketing, brand equity, preference, loyalty, price premium, luxury brands, international

\footnotetext{
1) Bruno.GODEY@ neoma-bs.fr
} 